\title{
A Retrospective Assessment of Specific Learning Disorders
}

\author{
Ömer Karaman ${ }^{1}$ \\ ${ }^{1}$ Ordu University Education Faculty the Department of Guidance and Counseling, Ordu/Turkey \\ Received: 03 April 2018 Accepted: 05 April 2018, Published online: 20 April 2018 \\ (C) Ordu University Institute of Health Sciences, Turkey, 2018
}

\begin{abstract}
Objective: Specific learning disorders (SLD) are delays or deviations observed in an individual's ability to speak, read, write, understand and do arithmetic. Diagnosis and the educational process is very difficult. Abnormalities of the central nervous system are shown as the cause of SLD, in addition to hereditary and environmental interactions. SLD has four subareas of reading disorder (dyslexia), written comprehension disorder (dysgraphia), mathematic disorder (dyscalculia) and other types. SLD may be accompanied by attention deficit and hyperactivity disorder, depression, anxiety, emotional and social problems. Epidemiological research has found rates of 1-33\%. The lack of clarity in SLD criteria with very different rates of diagnosis may be linked to the difficulties of diagnosis and method deficiencies. Studies have shown it is observed more often in males in terms of gender, with no significant correlation between females and males. This study aimed to retrospectively assess SLD diagnoses from 2009 to 2017.

Methods: The study accessed data for all SLD children from 2009-2017 and included 846 child diagnoses in total.

Results: The study found the percentage of a population of 201,347 people aged from 0-18 years containing 197 SLD cases was $0.09 \%$. Single sample chi-square test observed a significant level of increase as the years passed. Additionally, in terms of gender, the incidence in males $(69.14 \%)$ was higher than in females (30.85\%). The increase in SLD according to year was identified to be significantly rapid.

Conclusion: According to the data obtained in the study, it was concluded that there is a need for in-depth research into topics from SLD diagnosis to methods on a country basis.

Key words: Specific learning disorder, retrospective assessment, increase rate of specific learning disorder
\end{abstract}

Address for correspondence/reprints:

Ömer Karaman

Telephone number: +90 5056487189

E-mail: okaraman44@ hotmail.com

DOI: $10.19127 / \mathrm{mbsjohs} .412311$

\section{Introduction}

Diagnosis of learning difficulties includes a range of difficulties in terms of education and life adaptation, because learning processes are a complicated construct and as a result it is not easy to find a solution (Saenz et al., 2005). Additionally, the inclusion of factors like individual differences and intelligence points or visual acuity within the process may be listed as other difficulties (Özyürek, 2003). As a result, there are problems experienced in the diagnosis and education of those with learning difficulties both globally and in Turkey.

Specific learning disorders (SLD) encompass disorders determined as delays or deviations in speaking, reading, writing, comprehension and arithmetic gains and in using them fluently in life. 
Central nervous system anomalies are shown as the cause of SLD (Asfuroğlu and Fidan, 2016). However, hereditary qualities and environmental interaction are also stated as causes (Karaman et al., 2012).

Reading disorder (dyslexia), written comprehension disorder (dysgraphia) and mathematic disorder (dyscalculia) within SLD may be observed alone or together (Gorker et al., 2017). As a result, there are difficulties experienced with diagnosis. However, early diagnosis and rehabilitation is necessary in terms of academic gains and increased quality of life (Tore, Balazs, 2015).

SLD is most commonly accompanied by attention deficit and hyperactivity disorder (ADHD) (Beitchman and Young, 1997). Additionally, emotional problems, socialization problems, behavior including crime, anxiety and depression are commonly observed (Beitchman et al., 2001; Kempe et al. 2011). A study identified high anxiety and depression among students with SLD (Deniz et al, 2009)

The number with SLD is great; however, sufficient studies have not been reported (Yao and $\mathrm{Wu}, 2003)$. Epidemiological studies related to SLD have found different results. As there are no definite criteria defined in epidemiological studies, academic performance and other assessments are completed (Gorker et al., 2017). As a result, due to relative evaluations, results of $1-33 \%$ are encountered in the literature (Asfuroglu and Fidan, 2016).

This study performed a retrospective assessment of the prevalence of SLD. Thus, the proportional increase rate was assessed between the years and additionally proportions related to prevalence are presented. This study will contribute to the very few epidemiological studies in the literature. Additionally, there are no studies about the increase rate of SLD through the years found in the literature. This situation is the subjective construct in this study.

\section{Methods}

The Ministry of National Education definitions related to special education for those with disabilities, placement in an educational organization and monitoring processes were laid out in the framework of the special education services regulations in the Official Gazette number 26184 published in 2006 (OEHY, 2006). In line with this, all disabled individuals were determined, with educational placement processes organized by special education service boards in each province and large counties. The technical infrastructure services (diagnosis, placement, monitoring and support reports and recommendations) for processes organized by the boards are provided by counseling and research center directorates. As a result, documentation and archives are held in these centers. This research, run as a retrospective cohort study, assessed the statistical data related to SLD held by Altınordu Counseling and Research Center Directorate Special Education Department Chair in Ordu province from 2009 to 2017 after receiving necessary permissions. The study accessed data for all children with SLD for the years from 2009 to 2017 and included a total of 846 pediatric diagnoses.

\section{Statistical Analysis}

Relationships between variables were explored using the one-sample chi-square test and twosample chi-square test. Data were analyzed using SPSS 25 software (SPSS, Inc., Chicago, IL, USA). An alpha level of $5 \%$ was used for all statistical tests.

\section{Results}

The study found the 197 SLD individuals in a total population aged from $0-18$ years of 201,347 individuals was equivalent to $0.09 \%$.

According to the single sample chi-square test, there was a significant level of increase observed through the years $(\mathrm{df}=8, \mathrm{p}=0.000)$. However, there was no significant correlation with gender through the years (chi-square test; $p=0.745$ ).

Table-1. Distribution of specific learning disorder levels according to year and

\begin{tabular}{|c|c|c|c|}
\hline Years & Male & Female & Total \\
\hline 2009 & 9 & 7 & 16 \\
\hline 2010 & 13 & 7 & 20 \\
\hline 2011 & 17 & 10 & 27 \\
\hline 2012 & 46 & 24 & 70 \\
\hline 2013 & 70 & 30 & 100 \\
\hline 2014 & 75 & 31 & 106 \\
\hline 2015 & 101 & 37 & 138 \\
\hline 2016 & 124 & 48 & 172 \\
\hline 2017 & 130 & 67 & 197 \\
\hline Total & 585 & 261 & 846 \\
\hline P-Value ${ }^{1}$ & $\begin{array}{c}0.000^{* * *} \\
\left(\gamma^{2}=271.262 ; \mathrm{DF}=8\right)\end{array}$ & $\begin{array}{c}0.000 * * * \\
\left(\chi^{2}=111.310 ; D F=8\right)\end{array}$ & $\begin{array}{c}0,000 * * \\
\left(\chi^{2}=376,957 ; \mathrm{DF}=8\right)\end{array}$ \\
\hline \multicolumn{4}{|c|}{$\begin{array}{c}0.745^{\mathrm{NS}} \\
\left(x^{2}=5.119 ; \mathrm{DF}=8\right)\end{array}$} \\
\hline $\begin{array}{l}\text {, One- } \\
\text { est } \\
* *, \quad \mathrm{St} \\
\text { asignifi }\end{array}$ & $\begin{array}{l}\text { aple Chi-Squa } \\
\text { stically signif } \\
\text { it }(p>0.05) \text { bnh }\end{array}$ & $\begin{array}{l}\text { Test; 2, Two-s } \\
\text { at } \quad(\mathrm{p}<0.001) \text {; }\end{array}$ & $\begin{array}{l}\text { ple Chi-Square } \\
\text { Statistically }\end{array}$ \\
\hline
\end{tabular}


When the table is investigated, the percentage of males with special learning difficulties $(69.14 \%)$ was higher than for females $(30.85 \%)$. However, no significant difference was identified with the chisquare test $(\mathrm{p}>0.005)$.

Table 2. Incidence of Special Learning disorder in Ordu Province from 2009-2018

\begin{tabular}{cccc}
\hline Years & Total & Population & $\begin{array}{c}\text { Incidence Rate }(\mathbf{1 0 0 , 0 0 0} \\
\text { person-year) }\end{array}$ \\
\hline 2009 & 16 & 234,999 & 6.81 \\
2010 & 20 & 229,142 & 8.73 \\
2011 & 27 & 221,907 & 12.17 \\
2012 & 70 & 225,676 & 31.02 \\
2013 & 100 & 215,663 & 46.37 \\
2014 & 106 & 208,580 & 50.82 \\
2015 & 138 & 206,298 & 66.89 \\
2016 & 172 & 208,452 & 82.51 \\
2017 & 197 & 201,347 & 97.84 \\
\hline P-Value & \multicolumn{3}{c}{$\left(\chi^{2}=434.497 ; \mathrm{DF}=8\right)$} \\
\hline \multicolumn{4}{c}{$* * *$, Statistically significant according to two-Sample } \\
chi-Square test (p<0.001)
\end{tabular}

When the table is investigated, though the total pediatric population fell from 234,999 to 201,347 through the years, the number of children with SLD increased from 16 to 197. A significant difference was identified according to the chi-square test $(\mathrm{p}<0.05)$.

\section{Discussion}

According to the data obtained in the study the proportion of the total population aged from 0-18 years of SLD individuals was very low at $0.09 \%$. Studies in similar age groups have reached results showing the prevalence varies from $1-30 \%$ (Karaman et al., 2012). Differently, research by Rutter and Yule (1975) investigated 2300 children aged 9 years and identified a prevalence of 5\% (cited in Karaman et al., 2012). Polancyzk et al. (2007) identified a rate of 5\% in a society-indexed study. The study by Gorker et al. (2017) found a rate of $13.6 \%$. DuPaul and Stoner assessed different studies and identified a rate of $8.9 \%$ (cited in Gorker et al. 2016). A study in Turkey reported SLD rates of 37-38\% (Gorker et al. 2016). However, Lerner stated that the proportion of SLD individuals in the USA was $15-25 \%$ (Balci, 2017). Contrary to the different rates for prevalence, the incidence of SLD is accepted as 5-10\% (Karaman et al. 2012). Accordingly, the low rate obtained in the study is significant. SLD is high in reality; however, difficulties are experienced with diagnosis (Yao and $\mathrm{Wu}, 2003)$. Torgesen and Dice (1980) linked problems related to diagnosis to inability to clarify sampling variables in studies, differences in SLD definition and problems related to method. In line with this, the low percentage of the number of individuals with SLD obtained in this study may be linked to the lack of clarity of diagnostic criteria, difficulties with diagnosis and method deficiencies.

The incidence rate of SLD according to gender is higher in males, with uncertainties created by the different rates found (Rutter et al., 2004; Moll et al., 2014). Epidemiological studies have identified SLD incidence rates of 1.39-3.19 for males compared to females (Rutter et al., 2004). The incidence rate in males $(69.14 \%)$ was higher compared to females (30.85\%); however, there was no significant difference found. Similarly, research in the USA found rates of $67 \%$ in males and $33 \%$ in females in the 6-12 year-age group, with rates of $66 \%$ for males and 34\% for females in the 13-17 year-age group (Asfuroglu and Fidan, 2016).

The research investigated the SLD increase rates according to year. Accordingly, in the center of the study though there was a fall in the 0-19 year-old population rate, there was a significant increase in SLD diagnosis numbers through the years. There is no study encountered in the literature assessing according to year. Though the increase in SLD diagnosis according to year may be linked to the increase in parental educational levels and awareness studies about special education in recent years, significant factors may include causes such as nutritional habits, lack of smart medication use and bad living conditions.

In conclusion, due to the difficulties in diagnosing SLD, there is a need for a higher quality construct with objective quantitative data for diagnosis. Additionally, screening should be performed with a systematic plan within the framework of this construct. Later, in addition to quality education related to SLD, original studies related to causes should be performed. Studies will contribute to the universal dimension; however, there is a need for special studies on a regional or country basis, because studies in different countries have produced highly variable results. In Finland the SLD rate for 7-8 years' age group was 19.9\%; however, in Brazil rates of $7.6 \%$ were identified in children and adolescents (Taanila et al. 2014; Fortes et al. 2017). Among primary school children in Italy, this rate was $6.06 \%$ (Gorker et al., 2017). Different results may be obtained due to the language structure related to reading disorders included within the specific learning disorders. For example, English was determined to be a language with greater tendency to have higher reading disorder rates compared to Italian (Demonet et al., 
2004). Similarly, the incidence of reading disorder is greater for English compared to Japanese and Chinese (Stevenson et al. 1982).

\section{Conclusion}

According to the data obtained in the study, it was concluded that there is a need for in-depth research about topics from diagnosis to methods related to SLD.

\section{Acknowledgements:}

I wish to thank Ordu Counseling and Research Center for providing data and Lecturer Dr. Yeliz Kaşko ARICI for statistical assessment.

Ethics Committee Approval: Approval was received for this study from in Ordu Counseling and Research Center.

Peer-review: Externally peer-reviewed.

Author Contributions: Concept - ÖK.; Design Ö.K.; Supervision- Ö.K.; Materials - Ö.K; Data Collection and/or Processing - Ö.K.; Analysis and/or Interpretation - Ö.K.; Literature Review Ö.K Writing Ö.K.; Critical Review - Ö.K.

Conflict of Interest: No conflict of interest was declared by the authors.

Financial Disclosure: The author declared that this study hasn't received no financial support.

\section{References}

Asfuroglu BO, Fidan ST. Spesific learning disorders. Osmangazi Journal of Medicine, 2016; 38 (Special Issue 1): 49-54.

Balci E. Facts about dyslexia: what is dyslexia and what is not? Trakya University Journal of Social Science 2017; 19(1): 1-17.

Beitchman JH, Young AR. Learning disorders with a special emphasis on reading disorders: a review of the past 10 years. J Am Acad Child Adolesc Psychiatry 1997; 36: 1020-32.

Beitchman JH, Adlaf EM, Douglas L, Atkinson L, Young A, Johnson CJ, et all. Comorbidity of psychiatric and substance use disorders in late adolescence: a cluster analytic approach. Am J Drug Alcohol Abuse 2001; 27: 421-40.

Demonet JF, Taylor MJ, Chaix Y. Developmental dyslexia. Lancet 2004; 363: 1451-1460.
Deniz ME, Yorganc1 Z, Özyesil Z. A Research on Investigating the Trait Anxiety and Depression Levels of the Students with Learning Disabilities. Elementary Education Online. 2009; 8(3): 694-708.

Fortes IS, Paula CS, Oliveria MC, Bordin IA, De Jesus Mari J, Rohde LA. A cross-sectional study to assess the prevalance of DSM-5 specific learning disorders in representative school samples from the second to sixth grade in Brazil. Eur Child Adolesc Psychiatry 2016; 25: 195207.

Görker I, Bozatlı L, Kormazlar Ü, Yücel Karadağ M, Ceylan C, Söğüt C, et. All. The Probable Prevalence and Sociodemographic Characteristics of Specific Learning Disorder in Primary School Children in Edirne. Arch Neuropsychiatr. 2017; 54: 343-349. DOI: 10.5152/npa.2016.18054:1-7.

Hammill DD. On defining learning disabilities: an emerging consensus. J Learn Disabil 1990; 23: 74-84.

Karaman D, Kara K, Durukan İ. Spesific learning disorders. Anatol J Clin Investig 2012; 6(4): 288-298

Kempe C, Gustafson S, Samuelsson S. A longitudinal study of early reading difficulties and subsequent problem behaviors. Scand J Psychol 2011; 52(3): 242-50.

Moll K, Kunze S, Neuhoff N, Bruder J, SchulteKörne G. Spesific Learning Disorder: Prevalance and Gender Differences. PLoS ONE 2014; 9: 1-8.

ÖEHY, Özel Eğitim Hizmetleri Yönetmeliği, Devlet Bakanlığı ile Milli Eğitim Bakanlığından 31.05.2006 tarih ve 26184 say1lı Resmî Gazete. https://orgm.meb.gov.tr/meb_iys_dosyalar/2012 _10/10111226 ozel egitim hizmetleri_yonetm eligi son.pdf (Ulaşım: 02.04.2018).

Özyürek, M. (2003). Öğrenme güçlüğü gösteren çocuklar. (Ed: A. Ataman) Özel Gereksinimli Çocuklar ve Özel Eğitime Giriş. Ankara: Gündüz Eğitim ve Yayıncılık

Polanczyk G, de Lima MS, Horta BL, Biederman J, Rohde LA. The worldwide prevalence of ADHD: a systematic review and metaregression analysis. Am J Psychiatry 2007; 164:942-948.

Rutter M, Caspi A, Fergusson D, Horwood IJ, Goodman R, Maughan B, Moffitt TE, Meltzer H, Carroll J. Sex differences in developmental reading disability: new findings from 4 epidemiological studies. JAMA 2004; 291:2007-2012. 
Saenz LM, Fuchs LS, Fuchs D. Peer- assisted learning strategies for English language learners with learning disability. Exceptional Children. 2005; 71(3): 231-247.

Stevenson HW, Stigler JW, Lucker GW, Lee S, Hsu C, Kitamura S. Reading disabilities: the case of Chinese, Japanese and English. Child Dev 1982; 53: 1164-1181.

Taanila A, Ebeling H, Tiihala M, Kaakinen M, Moilanen I, Hurtig T, Yliherva A. Association between childhood specific learning difficulties and school performance in adolescents with and without ADHD symptoms: a 16-year follow-up. J Atten Disord 2014; 18: 61-72.

Torgesen JK, Dice C. Characteristics of research on learning disabilities. J Learn Disabil 1980; 13: 531-35.

Toro K, Balázs. The importance of early diagnosis and intervention in children diagnosed with reading disorder. Case studies. J. Neuropsychopharmacol. 2015; 17(2): 99- 103.

Yao B, Wu HR. Risk factors of learning disabilities in Chinese children in Wuhan. Biomed Environ Sci 2003; 16: 392-397. 